\title{
非領域表在性リンパ節転移により発見された前立腺癌の検討
}

\author{
千葉大学医学部泌尿器科学教室（主任：伊藤晴夫教授） \\ 古谷 雄三 秋元 晋 赤倉功一郎 伊藤 晴夫
}

\section{CARCINOMA OF THE PROSTATE PRESENTING AS NON-REGIONAL SUPERFICIAL LYMPHNODE METASTASIS}

\author{
Yuzo Furuya, Susumu Akimoto, Koichiro Akakura and Haruo Ito \\ Department of Urology, School of Medicine, Chiba University, Chiba, Japan \\ (Director: Prof. H. Ito)
}

(Background) The objective of this study is to evalute the prognosis of carcinoma of the prostate presenting as non-regional superficial lymphnode metastasis.

(Methods) From 1986 to 1996 at the Chiba University Hospital, 205 cases of prostatic cancer with distant metastasis were experienced.

(Results) In nine of them, non-regional lymphnode metastasis was observed at the diagnosis. In all of them, serum prostate specific antigen and/or prostate acid phosphatase levels were elevated. In eight of nine cases, cancer nodule was detected by digital rectal examination. Anti-androgen therapy was effective in eight cases and five year survival rate was $56 \%$.

(Conclusion) From these observations, prostate cancer should be considered when superficial lymphnode was enlarged.

Key words: prostatic cancer, non-regional lymphnode

要旨：(背景と目的）非領域表在リンパ節腫瘍をみた前立腺につき治療法，予後を検討した.

（対象と方法）1986年より1996年までに千葉大学泌尿器科で経験した stage D2前立腺癌205例のうち非 領域表在リンパ節腫脹を主訴とした 9 例を対象とした。

(結果) 全例で前立腺特異抗原（PSA），前立腺酸性フォスファターゼが高值を示し直腸診にて 9 例中 8 例に前立腺の硬結を触れた。転移リンパ節に対し PSA に対する抗体を用いた免疫組織化学が前立腺 癌の診断に有用であった。内分泌療法が奏功し長期生存する例もあった.

（結論）表在性リンパ節を触れる高齢者は前立腺癌を念頭に置き，診断，治療を進めるべきと考えた。 キーワード：前立腺癌，非領域リンパ節転移

\begin{abstract}
緒言
前立腺癌において他臟器への転移は稀ではなく，主 としてリンパ節, 骨, 肺などに認められる.しかしリ ンパ節転移は領域リンパ節がほとんどであり, 所属リ ンパ節以外への転移はきわめて稀とされている.今回， 非領域表在リンパ節腫脹を主訴とした前立腺癌症例に つき治療法, 予後について検討した。
\end{abstract}

\section{対象および方法}

1986年より1996年までに千葉大学泌尿器科で経験し た病期 D2前立腺癌205例のうち非領域表在リンパ節腫 脹を主訴とした 9 例を対象とした. 9 例中 8 例が内科, 放射線科より紹介され，8例中 7 例に内科, 放射線科
にてリンパ節生検が施行され, 腺癌, 未分化癌の診断 で原発巣としての泌尿器癌を疑われ当科を紹介され た。症例 5 のみがリンパ節腫脹とともに排尿困難を訴 え泌尿器科初診となった。9例すべてが前立腺癌に対 し無治療であり, 診断後内分泌療法 $(8$ 例に精巣摘除, その後 2 例にはエストロゲン剂内服， 4 例には酢酸ク ロルマジノン，1例にはフルタミド内服，1例は LHRH アナログとフルタミド)を施行した ${ }^{11}$. 4 例に対し ては内分泌療法とともにシスプラチンを中心とした多 剂併用化学療法を施行した ${ }^{2)}$.

前立腺特異抗原 (PSA), 前立腺酸性フォスファター ゼ (PAP) は栄研キット（正常值おのおの $3.0 \mathrm{ng} / \mathrm{ml}$ ) 
表 1 対象

\begin{tabular}{|c|c|c|c|c|c|c|c|}
\hline No. & 年秚命 & 主訴 & リンパ節 $(\mathrm{cm})$ & 分化度 & 治療前 PSA & EOD & $\begin{array}{l}\text { マーカー } \\
\text { 反応性 }\end{array}$ \\
\hline 1 & 45 & 左鎖骨上部腫脹 & 左鎖骨上 $(7 \times 10)$ & 低 & 8,800 & 4 & PR \\
\hline 2 & 62 & 左鼠径部腫脹 & $\begin{array}{l}\text { 左鎖骨上 }(1 \times 1 ， 4 \text { 個 }) \\
\text { 径(小鷄卵大) }\end{array}$ & 中 & 7.4 & 0 & $\mathrm{CR}$ \\
\hline 3 & 56 & 左鼠径部腫脹 & 左鼠径 $(4 \times 3,5 \times 3)$ & 中 & 620 & 3 & PR \\
\hline 4 & 81 & 前胸部腫脹 & 前胸部 (小児頭大) & 中 & 2,768 & 3 & 不能 \\
\hline 5 & 63 & $\begin{array}{l}\text { 左鎖骨上部腫脹 } \\
\text { 排困難 }\end{array}$ & 左鎖骨上 $(2 \times 2)$ & 中 & $101(\mathrm{PAP})$ & 0 & PR \\
\hline 6 & 70 & $\begin{array}{l}\text { 精栄痛 } \\
\text { 左鎖骨上部腫脹 }\end{array}$ & 左鎖骨上 $(2 \times 2)$ & 低 & 61 & 1 & $\mathrm{NC}$ \\
\hline 7 & 81 & 左鎖骨上部腫脹 & $\begin{array}{l}\text { 左鎖骨上 }(2 \times 2) \\
\text { 鼠径 }(2 \times 2,1 \text { 個づ } \\
\text { つ) }\end{array}$ & 低 & 197 & 2 & $\mathrm{NC}$ \\
\hline 8 & 62 & 季肋部痛 & 季助部痛 (手挙大) & 低 & 27 & 0 & $\mathrm{CR}$ \\
\hline 9 & 66 & 頝部腫脹 & $\begin{array}{l}\text { 左鎖骨上 }(3 \times 3) \\
\text { 右径 }(2 \times 2)\end{array}$ & 低 & 25 & 2 & $\mathrm{CR}$ \\
\hline
\end{tabular}

によった. PSA およびPAPによる効果判定は，治療 開始後 3 力月の時点で前立腺癌取扱い規約 ${ }^{3)}$ にり判 定した. 組織学的分化度は前立腺癌取扱規約にもとづ き高分化型，中分化型および低分化型に分類した。骨 転移の広がり（EOD）は骨シンチグラフィーを soloway らの方法4)で判定した. ホルマリン固定パラフィ ン包埋標本の PSA 免疫組織染色は山口らの方法 ${ }^{5} に$ よった.

\section{結 果}

（1）年齢：45歳より81歳まで分布し，平均65歳で あった。

（2）組織学的分化度：中分化型 3 例，低分化型 5 例 であり高分化型は認めなかった(表 1 )。症例 4 はリン パ節生検で未分化癌であったが全身状態悪化のため前 立腺生検を施行できなかったが剖検にて中分化型腺癌 の所見であった。原発巣は全例小鷄卵大より鵎卵大で, 症例 6 を除き触診にて明らかな硬結を触知した。

（3）転移部位：4 例は鼠径部リンパ節に転移を認 め，7例は鎖骨上リンパ節と思われる転移を，1 例は 傍大動脈リンパ節を季肋部に認めた. 3 例に複数部位 の触知可能な非領域リンパ節の転移を認めた。症例 1 , $2,4,6$ に傍大動脈リンパ節の腫大を，症例 1,2 に骨盤内のリンパ節腫大を認めた.リンパ節以外の転 移巣として 6 例に骨転移を認めたが，3 例は骨転移を 認めなかった．9例とも肺，肝などリンパ節，骨のほ かに転移を認めなかった、リンパ節よりの原発巣の診 断の一助として 4 例に PSA の免疫組織染色を施行し た ${ }^{5)}$. 施行した全例で腫崵細胞の細胞質が陽性に染色 され，転移巣でも前立腺癌の特徵を有していた。
表 2 治療および予後

\begin{tabular}{c|l|l}
\hline No. & \multicolumn{1}{|c}{ 治療法 } & \multicolumn{1}{|c}{ 予後 } \\
\hline 1 & 去勢+フルタミド & 9 カ月生存 \\
2 & 去勢+䣷酸クロルマジノン,EAP*6クール & 7 年 9 カ月癌死 \\
3 & 去勢+酷酸クロルマジノン & 7 カ月生存 \\
4 & LHRH アナログ+フルタミド & 1 カ月癌死 \\
5 & 去勢+エストロゲン, IAP**4クール & 5 年 3 カ月癌死 \\
6 & 去勢+酢酸クロルマジノン,EAP2クール & 1 年 7 カ月 \\
7 & 去勢+クロルマジノン & 2 年 3 カ月生存 \\
8 & 去勢+エストロゲン & 6 年 5 カ月生存 \\
9 & 去勢+エストロゲン, EAP 1 クール & 2 年 8 カ月癌死 \\
\hline
\end{tabular}

*Etoposide, Adriamycin, Cisplatinum

${ }^{*}$ If osfamide, Adriamycin, Cisplatinum

（4）腫瘍マーカー：治療前 PSA を測定できた 8 例 全例で PSA の上昇 $(7.4 \sim 8,800 \mathrm{ng} / \mathrm{ml}$, 平均 $1,563 \mathrm{ng} /$ $\mathrm{ml}$ )を認めた。症例 5 の治療前 PAP は $110 \mathrm{ng} / \mathrm{ml}$ と高 度上昇を示した。

（5）治療経過：9例すべてに精巣摘除術を中心とし た内分泌療法を施行した (表 2 )。 3 力月後の腫瘍マ一 カーの反応性は CR 3 例, PR 3 例, NC 2 例であった が CR 例と PR，NC 例のあいだに予後の差を認めな かった.転帰として 5 年生存率は $56 \%$ であり病期 D2前

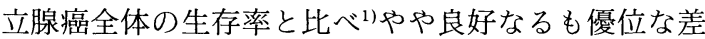
を認めず,最長 7 年 9 力月の生存を認める例もあった. 9 例中生存期間の長かった 3 例では初診時骨転移を認 めなかった。

\section{考 察}

近年前立腺癌患者数は増加の一途をたどり，今後も 欧米化していくと思われる。本邦では初診時に転移病 
変を有する例が約半数を占めており前立腺に限局した 前立腺癌の割合が欧米に比べ低( ${ }^{6}$. 病期 D2の転移部 位は骨が多く，初診時にリンパ節転移を体表から触知 できる例は稀であり, Corriere ら7は前立腺癌525例中 リンパ節腫大を主訴としたのは 2 例のみと報告してい る。増田ら ${ }^{8)}$ はリンパ節転移を主訴とする前立腺癌の 本邦報告例を16例集計している。 また山中ら ばリン パ節転移により腹部腫瘤の触知できる本邦前立腺癌 13 例を集計しており，リンパ節転移を初診時より触知す る前立腺癌の報告例は極めて稀と思われる。われわれ は非領域表在リンパ節腫脹を主訴とした前立腺癌 9 例 を経験した。

前立腺癌のリンパ節転移の好発部位は, 解剖学的に 所属リンパ節である閉鎖リンパ節，内腸骨リンパ節， 外腸骨リンパ節であり, 次いで仙骨前リンパ節, 傍大 動脈リンパ節であるとされている ${ }^{10)}$. 自験例では非領 域リンパ節として鼠径リンパ節，鎖骨上リンパ節を認 めたが，骨盤内リンパ節，傍大動脈リンパ節に画像診 断上転移を認めた症例が多く, 病巣の拡大としての非 領域リンパ節と考えられた。リンパ節転移の有無は主 にCT 検查にて診断しており診断的リンパ節廓清は施 行しておらず，骨盤内リンパ節転移なしとした例でも 微小転移の可能性は十分にあると思われる. 自験例 9 例中 6 例では同時に骨転移を認めたが， 3 例では骨ス キャン上転移を認めなかった.リンパ節転移と骨転移 の関係についてはそれぞれ別個の経緯で起こるといわ れており ${ }^{10)}$ 自験例でもそれを示唆する転移像であっ た。

近年 PSA おるよ゙ PAP に対する特異的な抗体の発 達により原因不明の腺癌の原発巣の診断にこれらを用 いた免疫組織化学の有用性が報告されている 例では排尿障害を主訴としたものは 1 例のみであっ た。触診では比較的容易に前立腺癌を疑えたが, 触診 にて著変を認めない例もあり, 補助療法としての免疫 組織化学の必要性が考えられる. 自験例でも症例 4 , $6,7,9$ において PSA 陽性細胞が認められ前立腺癌 のリンパ節転移の診断に有用であった。

治療としては非領域リンパ節転移を認めた前立腺癌 の諸家の報告によれば, 通常の進行性前立腺癌と同様 に内分泌療法を中心として化学療法が行われてい $3^{11) ~ 14)}$. 自験例では全例精巣摘除術を中心とした内分 泌療法を施行し, 症例によってはシスプラチンを中心 とした化学療法を追加した。予後としては 1 力月より 7 年 9 力月の生存を認め, 他藏器転移を有する病期 D2
の前立腺癌の予後と比較して顕著な差を認めなかっ た. 9 例中 5 年以上生存した 3 例はいずれも初診時骨 転移を有していなかった。症例数は少ないが，リンパ 節のみに転移を有するものは骨転移を有するものと比 べ内分泌療法に奏功し，ホルモン依存性が長期に保持 される可能性があり，今後の検討課題と思われる。栘 鏡ら $\left.{ }^{15}\right)$ によれば 3 力月後の腫瘍マーカー(PSA および PAP) の反応性が stage D2前立腺癌の予後を最もよく 反映するという.自験例ではマーカーCR 例と PR, NC 例のあいだに予後の差を認めなかったが，これは症例 数が少なかったためと思われた. 初診時非領域リンパ 節転移を認めても治療に反応し，長期生存する例もあ り前立腺癌の診断がつき次第通常の骨転移を有する前 立腺癌と同様に内分泌療法を開始するべきであると考 えた。

\section{結 語}

非領域表在リンパ節腫脹を主訴とした前立腺癌 9 例 につき検討し以下の結果をえた。

1）全例で PSA およびPAPの上昇を認めた.

2） 9 例中 8 例で前立腺に硬結を触れ, 前立腺癌の診 断は容易であった。

3）PSAの免疫組織化学染色が診断に有用な例も あった.

4）内分泌療法に奏功し長期生存をみる例もあり, 通 常の進行性前立腺癌と同様に治療すべきであると思わ れた。

\section{文献}

1）秋元 晋, 赤倉功一郎, 布施秀樹, 島崎 淳, 矢谷 隆一：Stage D2前立腺癌の内分泌療法. 日泌尿会 誌, 79, 1-10, 1988.

2）秋元 晋, 赤倉功一郎, 正井基之, 島崎 淳: 前立 腺癌内分泌療法無効例と再燃例に対する化学療法 の効果. 泌尿紀要, 37, 31-37，1991.

3) 日本泌尿器科学会, 日本病理学会編: 前立腺癌取 扱い規約. 第 2 版, 金原出版, 東京, 1992 .

4) Soloway, M., Hardeman S., Hickey, D., Raymond, J., Todd, B., Soloway, S. and Moinuddin, M.: Stratification of patients with metastatic prostate cancer based on extent of disease on initial bone scan. Cancer, 61, 195202, 1988.

5）山口邦雄, 角谷秀典, 布施秀樹, 伊藤晴夫, 島崎 淳, 松峷理: 前立腺癌の前立腺酸性フォスファタ 一ゼ扔よび前立腺特異抗原の組織化学. 日泌尿会 誌, 77, 786-790, 1986.

6）島崎 淳：前立腺癌. 日泌尿会誌, 80, 1407-1416, 1989. 
7) Corriere, J. N., Cornog, J. L. and Murphy, J.J. : Prognosis in patients with carcinoma of the prostate. Cancer 25, 911-918, 1970.

8）増田 均, 山田拓巳, 長浜克志, 永松秀樹, 根岸壮 治：リンパ節転移に伴う症状を主訴とした前立腺 癌の 3 例. 泌尿紀要，38，1269-1272，1992.

9）山中正人，橋本寛文：下腹部腫溜を主訴とした前 立腺癌の 1 例. 泌尿器外科, 7, 603-606, 1994 .

10) Catalona, W.J. and Scott, W.W.: Carcinoma of the prostate. In Campbell's Urology. 5th ed., P1473-1474, Saunders Co., Philadelphia, 1986.

11) Sater, G., Fossa, S.D., Ous, S., Blom, G.P. and Kaalhus, O.: Carcinoma of the prostate with soft tissue or non-regional lymphatic metastases at the time of diagnosis: A review of 47 cases. Br. J. Urol., 56, 358-390, 1984.

12) Tolia, B.M., Nabizadeh, I., Bennett, B., Newman, H.R. and Whitmore, W.F. : Carcinoma of prostate presenting as retroperitoneal mass. Urology, 12, 434-437, 1978.

13）藤田竜二, 永井 敦, 津川昌也, 那須保友, 津島知 靖, 大森弘之：リンパ節転移により発見された前 立腺癌の 1 例. 西日泌尿, 58, 41-43, 1996.

14）池田一則, 丹羽直樹, 岡史 篤, 伊藤 博, 阿部裕 行, 中神義三：鼠径部腫瘤を主訴とした進行性前 立腺癌の 1 例. 泌尿紀要, 37, 765-767, 1991.

15）桝鏡年清, 秋元 晋, 赤倉功一郎, 島崎 淳, 村上 信乃：病期 D 2 前立腺癌の予後因子, 泌尿紀要, 42, 269-274, 1996.

（1997年 2 月27日受付，7月31日受理） 